\title{
2 Theories Explained and Methodology Used
}

Knowledge is a resource with a capacity to flow, but within channels defined by the social structure of any particular period.

Vilhelm Aubert ${ }^{12}$

\subsection{Introduction}

Works of social science require that we use theory or theories upon which we base our sampling or data collection. And in interdisciplinary research, there are sometimes more theories than normal since two, or more, disciplines are involved.

In this chapter, I begin with asking what is a "norm?” Then I ask what a social norm is and what a legal norm is and if there is any difference between the two? I then describe a theory that the law uses to separate social norms from legal adjudication. This theory is called the ATL or Autonomy Thesis of Law. Following a description of this I offer more elaboration on the ATL by Brian Tamanaha and his socio-legal positivist theory of law formation.

Finally, I set out the main theories used in this book - the Jasanoff theory of the co-production of knowledge which I use since I want to address the idea of how we know what we think we know at any given time and apply that to how legislators and citizens knew what they thought they knew at the various times these laws were passed. Jasanoff's "field" theory is supplemented by the feminist theory of "intersugjectivity" which I also describe, below.

I also describe the Pescosolido model for large-scale structural changes that societies experienced since the passage of time that I deal with here is so great; fairly monumentous changes took place over this 100 plus year period..$^{13}$ I also provide some information on moral panics and how they can impact thinking. I also described critical discourse theory which helps in the selection of data from the discourse field and at address the question of which level - th emicro-, meso-, or macro-level - data must be taken. Social movements are also touched upon.

But first, we need to ask, "What are Social and Legal Norms?" Are social norms and legal norms the same? If they are similar, how do they overlap? It might seem over cautious to discuss this question but experimental designs require that we examine

12 Vilhelm Aubert, "The Professions in Norwegian Social Structure" in Transactions of the Fifth World Congress of Sociology, Vol. III as reprinted by International Sociological Association, 1964, p. 253. (Emphasis mine.)

13 Bernice A. Pescosolido-Rubin and Beth A. Rubin, “The Web of Group Affiliations Revisited: Social Life, Postmodernism, and Sociology” in American Sociological Review, 65 (2000), 67. 
apples with apples, etc. If there is a difference between social and legal norms, we need to know this.

\subsection{What are Social and Legal Norms?}

Theories of social action based on norms have been developed ever since the beginnings of Sociology. By the mid-20 $0^{\text {th }}$ century, Jack Gibbs stressed the lack of agreement on the definition of a norm, citing varying definitions from Robert Bierstadt, Leonard Broom and Philip Selznick, George C. Homans, Harry M. Johnson, Richard T. Morris, Theodore M. Newcomb and Robin M. Williams. ${ }^{14}$ However, Norwegian academic Ragnar Rommetveit observed that there was some conceptual agreement on the uses of the term. As he wrote in Social Norms and Roles there were three uses of the term. They were:

1. to indicate uniformities in behavior, 2. to designate a particular 'frame of reference' and, 3. to express the existence of social obli-gation or pressure. ${ }^{15}$

The problem with finding a definition of "norm" is that so many types of behavior are involved and reduction of these heterogeneous behaviors to one generalizable definition is perhaps impossible. But Gibbs made a convincing case that there is a way to define a generic norm. He gives three attributes of the generic constituents of a norm. They are, 1. collective evaluations, i.e. what ought to be, 2. collective expectations, i.e. what will be, and 3. reactions to behavior, i.e. the application of sanctions or inducements to a particular type of behavior. ${ }^{16}$

Sociologists in the present time are more apt to concentrate on the functions and mechanisms of norms. Peter M. Blau (1918-2002) conceived of norms - and values as mechanisms by which social structures can mediate among themselves in a society. He wrote:

Commonly agreed upon values and norms serve as media of social life and as mediating links for social transactions. They make indirect social exchange possible, and they govern the process of social integration and differentiation in complex social structures as well as the development of social organization and reorganization of them. ${ }^{17}$

14 Jack P. Gibbs, "Norms: The Problem of Definition and Classification" in The American Journal of Sociology, 70 (1965), 586-87.

15 Ibid., p. 587. Also see Ragnar Rommetveit, Social Norms and Roles (Minneapolis: University of Minnesota Press, 1955), 18-26.

16 Ibid., 589-90.

17 Peter M. Blau, Exchange and Power in Social Life (New York: Wiley, 1965), 255. 
The reason that I prefer this definition of norms/values is that it gives a method that extends across the social continuum from the micro- to the macro-level.

Work on human norms is also the provenance of research on the individual, such as in the work of George Homans (1910-1989). Homans based some of his fundamental propositions on interacting individuals and psychological principles. As he wrote:

The great example of a social fact is a social norm, and the norms of the groups in which they belong certainly constrain toward conformity the behavior of many more individuals. The question is not that of the existence of constraint but of its explanation... The norm does not constrain automatically: individuals conform, when they do so, because they perceive it is to their net advantage to conform, and it is psychology that deals with the effect on behavior of perceived advantage. ${ }^{18}$

I accept what Homans says with the possible exception of his claim that a "fact" is a "norm." However, in these two short quotations, we can find most of the fundamental ideas that influence those who research social and legal norms; for example, what is the role of psychology on adjudication by judges or acceptance of "what everyone knows is true" by a citizen, or does law really induce conformity based on rationality and how do structures, schemas (rules) and resources produce change? Homans was the founder of "exchange theory." Richard Emerson has extended Homans' ideas into what is called the "network exchange theory" and both of these theorists assume that actors are not always rational but that social relations can be explained through the use of both micro-and macro-level processes and phenomena.

Although many have contributed to our understanding of social action and the social norm, I am sympathetic to the Blau and Homan definitions, which I believe, cover both actions and norms. That is, a social norm or a social fact is something that is commonly agreed upon and serves as the medium of social life and as a mediating link for social transactions. Norms/values make indirect social exchange possible, and they govern the process of social integration and differentiation in complex social structures as well as the development of social organization and reorganization of these organizations.

An opposing view to this is taken by Stephen Turner, who has tried to address norms in terms of habits and practices and found that practices cannot be both causal and shared and that we can never hope to "get behind the notion of practice, either in a causal or a justificatory way, because practices are not objects...." ${ }^{19}$ In this sense, practices are the "vanishing point" of twentieth century philosophy. ${ }^{20}$ I prefer the

18 George C. Homans, The Nature of Social Science (New York: Harcourt, Brace and World, 1967), 50. 19 Stephen Turner, The Social Theory of Practices: Tradition, Tacit Knowledge and Presuppositions (Cambridge: Polity Press, 1994), 123.

20 Ibid., 1. 
ideas of Blau and Homans, even though and admittedly, the idea of a "norm" is still uncomfortable - unless one accepts non-linear and intertwined explanations.

But perhaps the liveliest definition of norms/values, for my taste, is that given by Norwegian legal theorist Nils Kristian Sundby, who wrote,

My fundamental concept of norms is thus so wide that it could cover the fire regulations on board a boat, ...private contracts, rules on what constitutes "offside" in soccer, individual moral judgments, mathematical proof principles, the commands of a general to his subordinates, the claim of scientifically correct observation,... [and] the ritual of high Mass on Sundays,... among other things. ${ }^{21}$

At this juncture, we turn to legal norms. What are they? Do social norms have some, most, or all, of the same generic constituents as legal norms? In other words, do legal norms even exist? Here I should note that legal theorists refer to "legal norms" as the laws themselves and the normative guidelines within those laws and judges also claim a set of ethical and adjudicatory "norms." Beyond that, legal theorists do not think in terms of "norms." By and large, what the layperson considers "legal norms" are, by and large, "social norms" and what legal theorists call "legal norms" evidence the same characteristics as what a law is.

The "father" of Sociology, Max Weber, approached the law by use of three "ideal types" - the moral, the dogmatic and the sociological. The moral attitude envisions the moral as outside the law, as extra-judicial. Exactly how, or even if, norms are incorporated into the law is not investigated. Law is used to render value judgments, from the "outside." Dogmatic jurisprudence is the vantage point of a judge or legal scholar. He or she can use the law for a purpose. The judge can render a decision in a particular case and the scholar can devise arguments that approve or disapprove of a certain law in the scholar has in mind. But Weber does say that this attitude also "end[s] in value judgments, judgments couched in the normative language of approval and disapproval."22

The use of these three "ideal types" gave Weber two advantages. First, ideal typology incorporates the idea of "understanding"23 the acts of groups or individuals by

21 Nils Kristian Sundby, Om Normer (Olso: Universitetsforlaget, 1974), p. 2. (My translation). Although Knut Bergo in Tekst og Virkelighet i Rettskilderlæren calls Om Normer, both "bitter" and "unrelenting” (p. 436), Bergo also notes that Sundby's concept of norms is a "relational” concept ("relasjonsbegrep") which is what I am interested in as an antidote to strong positivism. (p. 459) Please note that I do not rule out the existence of some universally held norms, e.g. torture or killing of innocents is wrong. One can also see why norm investigation has such received such bad press in legal academia, being labeled as "vague" by Eric Engle in "Law: Lex vs. Ius" in The Journal of Jurisprudence, 1 (2008), 31.

22 Anthony T. Kronman, Max Weber (London: Edward Arnold, 1983), 11. This book is part of a series entitled Jurists: Profiles in Legal Theory, whose general editor was William Twining.

23 In German, "Verständnis” (noun) or “verstehen” (verb). 
seeing the world from their standpoint and secondly, it incorporates an "interpretive" method that can be used to categorize social activities as well as helping to understand various societal patterns. ${ }^{24}$ This allowed him to "accentuate not [only] the generic similarities between cultural phenomen[a], but [also] their differences." 25 But, this ideal-type dialectic of Weber also had, and continues to have, drawbacks. Nevertheless, this "inside-outside" dichotomy continues to be used and also to create problems.

It is when Weber begins to write about the law vis-a-vis the economy that he notes that social norms can be incorporated into the law. He asks what significance, or "normative meaning ought to be attributed in correct logic to a verbal pattern having the form of a legal proposition"? ${ }^{26}$ If we look at the sociological point of view, as opposed to the legal point of view of this question, then one asks:

What actually happens in a group owing to the probability that persons engaged in social action (Gemeinschaftshandeln), especially those exert-ing a socially relevant amount of power, subjectively consider certain norms as valid and practically act according to them, in other words, orient their own conduct towards these norms. ${ }^{27}$

But, is this the last word from an upper-class man who supported the cause of small farmers in his own time, i.e. the Junker movement? Obviously, it is not and Weber's response to another legal thinker of this day, Rudolf Stammler, addresses the fact that social and legal norms can be similar.

Stammler wrote that the difference between a social norm (a convention) and a legal norm was that which utilized the free will of the individual. Weber ignored this idea and called it "of no use whatsoever."28 And here, we should perhaps stop to consider the common understanding of the sources of law. Most would agree that the sources of law exist in such things as customs, traditions, convention, religions, folkways, etc. Weber took this point of view writing that there "is no socially important moral commandment which has not been a legal command at one time or another."29 Weber considered that law and convention were so "intertwined as cause and effect in the actions of men, with, against, and beside, one another." ${ }^{30}$ For Weber, "law, convention, and custom are by no means the only forces" that control the conduct

24 The "verstehen" method is also known as the interpretive or hermeneutic approach.

25 Wolfgang J. Mommsen, The Political and Social Theory of Max Weber (Cambridge and Oxford: Polity Press, 1989).

26 Guenther Roth and Claus Wittich (eds.), trans. Ephraim Fischoff et. al. Max Weber, Economy and Society:An outline of interpretive sociology (Berkeley and Los Angeles: University of California Press, 1978), 311.

27 Ibid.

28 Ibid., 325.

29 Ibid.

30 Ibid., 327. 
of a person. There is also, for a person or a group, self-interest that conduct will continue. Sociology looks to empirical regularities as well as legal guarantees and "their underlying normative conceptions as causes or consequences of these regularities." ${ }^{1}$

This entire discussion leads to the point where one could conclude that both social and legal norms can have their formation in the social and that they can be studied empirically. As Scott Hamish writes, Weber's sociological point of view

reinforces the possibility that at a certain level of analysis there may be no incompatibility between (legal) conceptual analysis and sociology: indeed they may be entirely compatible. ${ }^{32}$

Of course, the vital section of this quotation is "at a certain level of analysis" and Hamish takes care to set these out as a combination of tasks. These tasks are:

an equally weighted but discriminating combination of ... 1. an analysis of existing conceptual frameworks for law, and 2. the use of newly constructed frameworks." ${ }^{33}$

As I noted above in my reference to Rommetveit, social norms have as their features, 1. to indicate uniformities in behavior, 2. to designate a particular 'frame of reference' and, 3. to express the existence of social obligation or pressure, I see no need to prolong this discussion of to what extent social and legal norms overlap. They sometimes overlap, partially or entirely to the point of being virtually congruent. This interwining effect makes it difficult to see much, if any, difference between legal and social norms. ${ }^{34}$

\subsection{A Theory of Legal Boundaries}

[T]he Leitmotif of legal positivism can be seen as the aspiration to secure for law an independent sphere within the realm of practical reason, which primarily is a matter of attempting to seal off, at the foundational level, 'law' and legal discourse from 'morality' and moral discourse.

Olsen and Toddington ${ }^{35}$

31 Hamish Ross, Law as a Social Institution, (Oxford: Hart Publishing, 2001), 90.

32 Ibid., 91.

33 Ibid., 94. Ross relies for this on the work of Robert Summers. Please see, Robert Summers, "The New Analytical Jurists" in New York University Law Review, 41 (1966), 861. Hamish also makes references to H.L.A. Hart's "nucleic expository theory."

34 Ragnar Rommeveit, Social Norms and Roles (Minneapolis: University of Minnesota Press, 1955), 18-26. I should leave room for the case where they do not overlap at all but this is a difficult case to imagine.

35 Henrik Palmer Olsen and Stuart Toddington, Law in its Own Right (Oxford and Portland: Hart Publishing, 1999), 31. 
The boundaries between laws and norms are always being negotiated and shifting in one way or another. The current boundaries between the law and social norms have already supposedly been constructed - and reinforced - by legal theorists over a long period of time. ${ }^{36}$ I want to emphasize that there are very good reasons for this, especially when one reviews the impact that pre-modern European religious forces had on weak civil laws.

But what has happened is that these boundaries act in a way that supports the idea that social norms might only exist and interact with the goal(s) of legislation up until the minute the law is passed in a procedurally appropriate manner. At that point, the law takes on a life of its own and enters a world of abstraction, of legal dogmatics and adjudication.

The ATL is advocated by theorists such as Gerald Postema. ${ }^{37}$ To be fair, the reasoning behind the ATL is persuasive, in the abstract. It also says that since human society is so complex and since we can never hope to achieve agreement by all interested parties, then we need to create a barrier for public officials who must use the law in question and also a cultural myth that claims influence by none of the parties. It is a type of "override mechanism." 38

Postema has three attached corollaries that are both "logically indispensible and logically interrelated.” They are the Limited Domain Thesis (LDT), the Pre-emption Thesis (PET) and the Source Thesis (ST). As Olsen and Toddington write, these three sub-theses mean (indeed, demand) that law is:

a body of "autonomous" norms, operates in a limited domain of practical reason common to
officials and citizens alike; that these norms constitute exclusionary reasons for action in that
they preclude and override conflicting reasons or normative preferences outside the domain,
and these, therefore preemptive, norms be identifiable at source without recourse to moral argu-
ment or political evaluations which might exist and function in various influential ways outside
the limited domain. ${ }^{39}$

This is all very convenient and can sometimes leave a significant minority at odds with enacted or adjudicated law or both. However, defining away problems through

36 However, one of the strongest modern proponents of this wall is sociologist Arthur Stinchcombe insofar as he supports the procedural formality of the law as a type of "blueprint" for the process of law. See, Arthur L. Stinchcombe, When Formality Works: Authority and Abstraction in Law and Organizations (Chicago: The University of Chicago Press, 2001). "My argument is that when law (or mathematics or organization) works, it is the same substance as the rest of social life, but formalized for one purpose or another." p. 3. Rheinstien notes that there are two types of formality, however, and Stinchcombe emphasized procedural formality at the expense of "sense" knowledge as a type of formality. 37 Gerald Postema, "Law's Autonomy and Public Practical Reason” in R.P. George, The Autonomy of Law: Essays on Legal Positivism (Oxford: Clarendon Press, 1996), 79-119.

38 Olsen and Toddington, Law in its Own Right, 30.

39 Ibid. 
the use of theory is not the best way of constructing a new theory. It is a bit like believing viruses do not exist as a source of infection because antibiotics kill bacteria. But, it is, nonetheless, very alluring - especially if far more bacteria than viruses exist.

Thus, the Autonomy Thesis of Law exists as supporting the "Berlin Wall” of social norm non-inclusion that I examine in this book. Many theorists have discussed this theory and found it wanting in one way or another - Gustav Radbruch for one - while others defend it at every turn. At the end of the day, the social (and legal) norms of stability and predictability seem to argue for the continuance of the ATL, in some form or another, although there seems to be no end to "conversions" away from it. ${ }^{40}$

Positive law is basically the written law of a country. It can be the result of legislation and adjudication based on challenges to laws and it can be found in printed form or some sort of media, for all citizens to read. It is published to citizens as part of a social contract. As American jurisprudential great H.L.A. Hart would write, it has no necessary connection with morality.

Positive law has several drawbacks as well as advantages. In some cases, it is vague. It is sometimes not well thought out, passed in haste, It can even be purchased through lobbying. In order to have determinate law at any given time, we cannot go behind it and reconsider it every time it is used. This is one of the reasons for the ATL. The problem with walls is that they not only keep something out but they also restrict what is being confined. For example, as I mentioned above, one can find perfectly acceptable reasons, given Western ideas of the separation of Church and State, for keeping the precepts of one religion or another behind this wall and away from being incorporated in positive law of any kind. But should some type of fundamental ethics or the results of social scientific inquiry also be excluded?

With regard to ethics and morality, some theorists assume that it is not, by definition, included - at least in adjudicated law. On the other hand, as Olsen and Toddington write, there is a "less than inspirational" thesis that there is a "moderate connection in some sense between law and morality." 41 Here is not the place to delve into the variations on this theme. I will note, however, that this issue can make for strange bedfellows. ${ }^{42}$

40 At the end of his life, legal theorist Neil MacCormick seemed to be one such convert to the belief that legal positivism was insufficient in itself. Please see Claudio Michelon, Jr.'s oving remembrance of MacCormick in Dritto \& questioni pubbliche, No. 9 (2009), 53-62.

41 Olsen and Toddington, Law in its Own Right, 18.

42 Ibid. These two authors cite to the fact that methodological and substantive natural law theorists such as John Finnis agree with methodological and substantive positivists such as Neil MacCormick that there is a necessary, i.e. not contingent, connection between law and morality. While there is often a consistent connection - at the practical level - between law and morality, I am of the opinion that there is no necessary connection between the two, and in this work am not advocating for the socalled "new" natural law by any means. 
An example of how this ATL Berlin Wall restricts use of social science can be found in McCleskey v. Kemp, 481 U.S. 279 (1987). In McCleskey, the United States Supreme Court (USSC) refused to consider empirical data on who received the death penalty and who did not. The data was part of the Baldus Study, which considered the race of victim and perpetrator as a factor in sentencing. Despite the statistical foundations and persuasiveness of this social science data in this study, the USSC refused to consider the study's conclusions as a means to reevaluating the on-going legal validity of the death penalty in McCleskey. Baldus showed a statistically significant correlation between the race of the victim and the perpetrator and the likelihood of the perpetrator to receive the death penalty. If justice was "blind" as those who support the Wall often presume, this could not be proven by the rejection of the Baldus Study or by its content and conclusions.

The theory of positive law continues as a strong theory although there are cracks in the wall which most simply overlook but which others cannot avoid acknowledging. ${ }^{43}$ One of the cracks begins with a very old idea, extant at least since Plato and Aristotle. This is that the law, in ways both large and small, does actually "mirror" society. This is the theme that Brian Tamanaha used to begin his study of a general jurisprudence theory that he calls socio-legal positivism. ${ }^{44}$ Indeed, one of the Judges we shall meet in this work, Oliver W. Holmes, the author of Buck v. Bell, 274 U.S. 200 (1927), called law a "magic mirror" of the lives of all people; this theory comes down to us as the "mirror thesis." 45 Justice Holmes both espoused the mirror thesis and also upheld the forced sterilization of Carrie Buck in Buck v. Bell, 274 U.S. 200 (1927) leaving us to wonder if the mirror thesis is a cogent argument against the erosion of this Berlin Wall. ${ }^{46}$

43 The ATL itself is the product of the theory of positive law. Positive law, while attacked from various quarters at various time periods, seems to be undergoing a sustained critique at this time. In point of fact, J.D. Goldsworthy has said that legal positivism has now "self-destructed." See, J.D. Goldsworthy, "Self-destruction of Legal Positivism" in Oxford Journal of Legal Studies, 4 (1990), 449.

44 Brian Z. Tamanaha, A General Jurisprudence of Law and Society (New York and Oxford: Oxford University Press, 2001).

45 Ibid., 2.

46 Buck v. Bell, 274 U.S. 200 (1927), case decided in the U.S. Supreme Court

While I am concerned with the refusal to admit the existence of this Wall by some who write at the border between sociology and law and with the ensuing schizophrenia in American law, I am also concerned with the function of the border. If the law is not "situated" (contextualized) in any sense of that word, then, and in anything other than an abstract manner, to use Thomas Nagel's phrase, is it not a "view from nowhere"? (Please see Thomas Nagel, The View from Nowhere (New York and Oxford: Oxford University Press, 1986). It may function to keep law "pure" in some primal, sacral sense but it also functions to give law a largesse that is unassailable, even when unreasonable, as was seen in McCleskey, above. The reasons for this can also be, at least partially, primal. The idea that "any law is better than no law" retains a salience, even though many now admit law is based in conventions and social norms and that law is overrated as a means for social order. 


\subsection{Tamanaha's Socio-legal Positivist Theory and Boundaries}

Anyone who begins to read jurisprudence will note that some ideas and themes may serve as the starting point for many interpretations. One such theme is the idea of social order. In western political thought from Hobbes to Rawls, this is, if not an obvious concern, then at least an underlying fear. As Tamanaha writes:

The implied threat of disorder works on our primal fears to render law in heroic terms, as a savior or protector; the metaphor of the mirror makes it our savior, our protector, a power to identify with, not fear. ${ }^{47}$

And here we have the second half of the mirror thesis, which is that law reflects society... so that order can be maintained. This also is a preview of one of my conclusions, namely, that at times of "moral panic" we often turn to the law as a protector against, for example, "race suicide." The emphasis on "law and order" may also be why the phrase "law and justice" has never held the public imagination as has the former.

Other central ideas in the study of jurisprudence are customs, reason and morality. Since I am concerned here, primarily, about the interaction between law and society, I take Tamanaha's model to demonstrate these ideas. He writes that Custom/ Consent and Morality/Reason, each from its own vantage point, impacts the making of Positive Law as demonstrated in Figure 2.1, below.

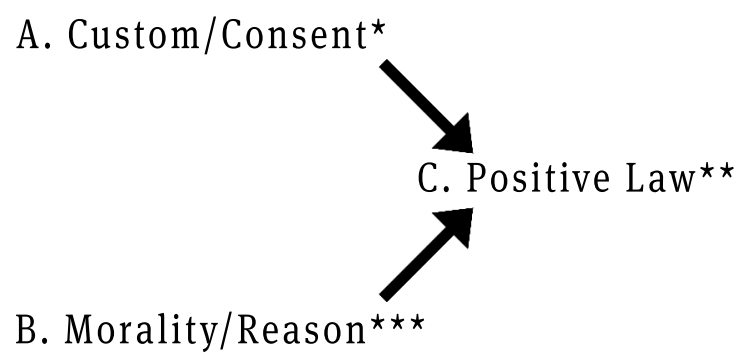

Figure 2.1: The Tamanaha relationship between law and society ${ }^{48}$

47 Tamanaha, A General Jurisprudence of Law and Society, 3.

48 Ibid., 4-5. * In this model, Custom/Consent refers to the "customs, usages, habits and practices of society." An example is the common law. ${ }^{\star \star}$ In this model, Positive Law is law that is written and that can then be enforced through coercion, if necessary, thus implying its attributes of both power and authority. ${ }^{\star \star \star}$ Morality/Reason refers to the customs that are perceived as "moral" or to the natural law, but it is not limited to it. In fact, some theorists would deny that positive law need have anything to do with morality (Austin) while others (Dworkin) see them as intertwined. 
All this - again - is about the problem of line drawing and the psychological certainty that hard and fast demarcations brings. How and where the lines are drawn among disciplines such as "politics" and "law" or among the various facets of "the social?" And, who draws these lines? And, one question that is sometimes omitted but perhaps the most important is "cui bonum" or "Who benefits by all this line drawing?" Where is the line drawn between, in this case, the Law and the socio-cultural?

It might be worth considering that rather than drawing lines between the worlds of politics and law that we might rather think of them as parallel lines, or layers. ${ }^{49}$ Not always unidirectional processes, they are more in the shape of lines indicating the ebb and flow between liquids of different tonic strength, i.e. $\Leftrightarrow .{ }^{50}$ Or, there might be connections between different layers. The ebb and flow of ions or the connections between multilayered phenomena are metaphors for the fact that history moves forward and backward, at the same time, which brings us to the issue of causation. Tamahana admits that these three areas do not act in a uni-directional fashion and therefore, I would amend his original figure, noted above, to more accurately reflect this so that the symbol $\rightarrow$ becomes the symbol $\Leftrightarrow$.

\subsection{Jasanoff and the Idiomatic Co-construction of Knowledge}

I use Sheila Jasanoff's social constructivist idiom methodology, although the entire theory of social construction has, and will continue to have, its detractors. ${ }^{51}$ Jasanoff, and others, have tried to answer the objections to social constructivism and I agree with her when she writes that the work done by Kuhn and others ${ }^{52}$ is captured "imperfectly" by the "dictum that scientific knowledge is socially constructed." 53 The problem with this overly simple formulation is that it "raises two [irresolvable] prob-

49 Ibid., 30. Citation to Pickering.

50 Let us suppose that "politics" might exist as the chemical silver nitrate (Ag2NO3) in a glass beaker. The beaker also holds "the social" or distilled water. In this analogy, when "the law" is added in the form of an acid such as hydrochloric $(\mathrm{HCl})$, various reactions take place in the solution, i.e. there is a precipitate, silver chloride ( $\mathrm{AgCl})$. But, by comparison, in an "isotonic" solution, the forward and backward reactions between elements in solution are in equilibrium. But if one has a hypotonic or a hypertonic solution (stress, "moral panic", economic disaster), the direction of fluids can be changed from forward to backward and vice-versa.

51 A recent good discussion of this can be found in John R. Searle's review of Paul A. Boghossian's book Fear of Knowledge: Against Relativism and Constructivism, in "Why Should You Believe It?” in The New York Times Review of Books, LVI, (2009), 88-91.

52 These others include, for example, Bloor, Collins, Kuhn, Latour and Woolgar.

53 Sheila Jasanoff (ed.), States of Knowledge: The co-production of science in social order (London and New York: Routledge), 19. 
lems, one theoretical and the other pragmatic." 54 To the first (theoretical) problem, she writes that there is no causal primacy in the "social."

Constructivism does not imply that social reality is ontologically prior to natural reality, nor that social factors alone determine the workings of nature; yet the rubric "social construction" carries just such connotations. ${ }^{55}$

The second (pragmatic) problem that Jasanoff notes is that, because of the large number of constitutive elements of the "social", there can be no "symmetrical probing" of all the elements at one time..$^{56}$ One element has to be made "fundamental, granted agency, and so exempted from further analysis." 57 Thus, she uses the four "fields" of making representation, making institutions, making discourses and making identities - as a method for exploring the factors involved in how knowledge is co-produced; my work will thus be descriptive in nature, looking at factors, perhaps arguing that one or another is "necessary" or "indicative" but not actually arguing causation.

While this may cause some discomfort, she assures us that co-production is neither random nor contingent. As she writes:

In each of these... areas - the emergence of new phenomena, the resolution of conflicts, the standardization of knowledge or technology, the enculturation of scientific practices - work in the co-productionist idiom stresses the constant intertwining of the cognitive, the material, the scientific and the normative. Co-production is not about ideas alone; it is equally about physical things. It is not only about how people organize or express themselves, but also about how they assume responsibility for their inventions. Equally and to the point, co-production occurs neither at random nor contingently, but along certain well documented pathways. ${ }^{58}$

With this in mind, it should not surprise the reader that some of the information about making representations, institutions, discourse and identities includes such disparate topics as sausage casings, exorcism and women dressed as men.

\subsection{Combining Intersubjectivity and the Jasanoff Fields}

In addition to Jasanoff's co-productionist idiom with its four fields of co-production, I also use here the theory of intersubjectivity, introduced by Leslie McCall, Patricia

54 Ibid.

55 Ibid.

56 Ibid., 19-20.

57 Ibid., 20.

58 Ibid, 6. 
Hill Collins and others. ${ }^{59}$ As Collins notes, the construct of intersubjectivity "references two types of relationships: the interconnectedness of ideas and the social structures in which they occur, and the intersecting hierarchies of gender, race, economic class, sexuality and ethnicity." ${ }^{00}$ In this theory, the categorical form of complexity takes as its beginning point that "there are relationships of inequality among already constituted social groups." ${ }^{61}$ While one must acknowledge that these social groups are "imperfect" and "ever changing", these groups are the centerpieces of the methodology. These groups are the anchor although their use may be provisional. ${ }^{62}$ The premise of the categorical complexity approach is that "relationships among social groups are containers of definable and indeed measurable inequalities." 63 The groups that I originally examined were based on ability, class, race/ethnicity, gender, and citizen status. As a sacrifice to space considerations, I will generally use one category as representative of some of the features that the others also show, and that one category is gender.

The ideas which we now know as intersubjectivity are a result of reflexive work done at the end of the twentieth century when traditional feminism was challenged to include a more complete picture of the master-subject relationship through the inclusion of other factors, especially gender, race and class. ${ }^{64}$ In the 1990s, these same factors were used to further refine feminist theory. New questions about the nature of repression in any of, or in a mix of, these categories have forced feminists to reconsider a newer "intersubjective" feminist paradigm.

My use of this theory, which includes these containers of identity, is an effort to honor the complexity of the times as well as a way to better outline the full impact that the laws had on these groups. ${ }^{65}$ Take, for example, Jasanoff's co-productionist idiom of the identity. In Case 1, one could select various identities through this theoretical lens; these included identities such as handicapped (ability), female (gender), non-white (race), poor (class) and immigrant (citizen status) and look at their role in

59 Leslie McCall, "The Complexity of Intersubjectivity" in Signs: Journal of Women in Culture and Society, Vol. 30, No. 3 (2005). McCall actually outlines three approaches to intersubjectivity, i.e. anticategorical complexity, intercategorical complexity and intracategorical complexity. Intersubjectivity is also called intersectionality by Feminist theorists.

60 Patricia Hill Collins, "Moving Beyond Gender: Intersectionality and Scientific Knowledge” in Myra Marx Feree, Judith Lorber and Beth B. Hess (eds.) Revisioning Gender (Walnut Creek \& Lanham: AltaMira Press, a Division of Rowman \& Littlefield Publishers, Inc., 2000), 263.

61 Ibid., 1785.

62 Ibid.

63 Ibid.

64 The "master-subject" reference is to work done by Carole Pateman in her various works such as The Sexual Contract (Cambridge: Polity Press, 1988).

65 We see the same groups of non-BMM ("non-benchmark male") people appear in the newspapers in Indiana, 1907 and Oslo, 1934 as well as - again - in Connecticut (1963) and Oslo (1976). As I mentioned earlier, this led me to consider this theory as a way of explaining their re-appearances. 
social/moral discourses, i.e. who will feed those who cannot work, what will happen if women can vote, what will happen especially to white women if blacks and whites mix, and what will happen to the country if the poor and "waves" of immigrants reproduce while upper-class white women do not?

The goal of the intersubjective approach is to consider the identity - usually imposed on the individual - of these categories and to compare their relationships, one or two at a time. While this way of managing complexity "at first appears to be a reductionist process", I would argue along with McCall, that it eventually becomes, in the end, "a synthetic and holistic process that brings the various pieces of the analysis together." 66

In a journal article entitled "The Race to Innocence: Confronting Hierarchical Relations among Women”, Marie Louise Fellows and Sherene Razack give an analysis of feminism that includes a discussion of why systems of oppression are so successful. They contend that social strategies and practices must account for the relationships among hierarchical systems.

Systems of oppression (capitalism, imperialism, and patriarchy) rely on each other in complex ways. This "interlocking" effect means that the systems of oppression come into existence in and through each other so that class exploitation could not be accomplished without gender and racial hierarchies, imperialism could not function without class exploitation, sexism and heterosexism, and so on. Because the systems rely on each other in these complex ways it is ultimately futile to attempt to disrupt one system without simultaneously disrupting others. ${ }^{67}$

I attempt to show how this theory of interlocking systems of oppression, including but not limited to that of women's oppression, can be used to create law for regulation, liberation or further oppression. The fact that oppression is an interlocking process also supports the idea that unjust laws are put into effect when several, or all, of the categories mentioned above are implicated.

Keeping in mind that this thesis is ultimately about how the law impacts the body and its reproductive capacities, in Case One in my discussion of identities I select events that demonstrate the ideograph of wife and mother. An ideograph is a normatively proper concept of woman or wife, i.e. at that time, of who should be deemed a good wife and mother. One of my concerns was to see if the categories stay in a container that remains non-porous even over the short term and in the same

\footnotetext{
66 Ibid., 1787.
}

67 Mary Louise Fellows and Sherene Razack, “The Race to Innocence: Confronting Hierarchical Relations Among Women” in Iowa Journal of Race, Gender and Justice, 1, (1998). In this paper the authors discuss the problem of competing marginalities and the belief that women do not see themselves as being implicated in the subordination of other women - women of color, lesbians, poor women, prostitutes etc. Women often claim that their own marginality is worse than some other sort of marginalism and that they have played no part in the subordination of other women. The authors have named this process "the race to innocence." 
place - as well as over the long term. Do the categories become multi-discoursed? If this happens, how do the containers change, do they remain intact or are they semiporous?

Historical considerations of sociological events are complex. The intersubjective approach posits that complexity derives from the fact that "different contexts reveal different configurations of inequality in [a] particular social formation." 68 The point, as McCall writes, "is not to assume [an] outcome a priori but to explore the nature and extent of such differences and inequalities." ${ }^{69}$ One can indeed begin with "traditional analytical categories as a starting point" but findings can be more "fruitful" - one of the indices of reliability ${ }^{70}$ - and go beyond a single finding to include multiple, interesting and conflicting findings. In her work, for example, she came to question whether the traditional indicators of inequality, such as family income inequality and male earnings could continue to be used as indicators of a "new inequality." this mean, in the end, that patterns couldn't be discovered? Some researchers, including N. Katherine Hayles, who have abandoned the predictability aspect of positivism, altogether believe not. They believe that simply because a phenomenon is complex "does not mean that anything goes: reality is complexly patterned but patterned nonetheless."72

For example, the category of (degenerate) identity was first linked to the criminal/ non-criminal category in the United States and, eventually to the cognitive/physical ability of both males and females, in Norway. The categories "morphed", intersecting with other categories. However, no matter what combination of categories came to exist, if we look at only the sheer number of people sterilized, a dramatically larger number of women than men were sterilized. ${ }^{73}$ Why was this so? In the United States in 1942, male criminals were left behind in the protective dust of legal precedent because of the due-process requirements of Skinner v. Oklahoma, while women, especially women of color, disabled and poor women, continued to be sterilized well into the 1970s in both countries. ${ }^{74}$ In other words, three-time convicted chicken thieves were

68 McCall, Complexity of Intersubjectivity, 1791.

69 Ibid.

70 Jonathon Potter argues that we can use four considerations to assess our work, 1 . deviant case analysis, 2. participants' understandings, 3. coherence and 4. readers' evaluations. Please see, Jonathon Potter, "Discourse analysis and constructionist approaches: theoretical background" in J. Richardson (ed.) Qualitative Methods for Psychological and the Social Sciences (Leicester: British Psychological Association, 1996).

71 Please see, Leslie McCall, "Explaining Levels of Within-Group Wage Inequality in U.S. Labor Markets" in Demography, 37 (2000), 415-30.

72 McCall, Complexity of Intersubjectivity, 1794.

73 Please see as regards the United States, Carey, "Gender and Compulsory Sterilization Programs in America: 1907-1950, Note 208. As regards Norway, please consult Per Haave's work on the sterilization work of Sámi and "travelers" (Roma) by the Oslo Indremisjonen.

74 Ibid. 
safer with regard to bodily integrity under the Constitution of the United States than poor, disabled and non-white women were. ${ }^{75}$ In Case Two, the same intersubjective categories come to the surface again, also during a time of social turmoil over values and within the same context of how the law regulates human reproduction. In Case Two, the groups that were less powerful in Case One had accumulated more power through various resources, schemas and structures and had changed to a point where an opposite result could be reached.

The problem with this type of argument is that the social script in many countries still normalizes the "benchmark male" (BMM) as a reference point. Benchmark male means "those who are white, able-bodied, heterosexual and middle class, and who constitute the normative standard within the social script." "Connell points out that these (male) hegemonic norms of gender can be known "at a given moment in time and cultural space."77 Connell calls this "hegemonic masculinity" and, when combined with the fact that access to the ballot box for over a century has not produced full participation by women in the liberal democratic process, makes us wonder what exactly has failed in the execution of a modern form of liberal government.

Margaret Thornton notes that "the imagery associated with the body politic has not undergone a sex change."78 This is so because the liberal project conveniently separated the public and the private sphere. And since "universal language [such as the law] denies embodiment and subjectivity altogether", any type of "particularities are relegated to the private sphere, which encompasses the affective and the corporal, reproduction and nurturing - notions that have all come to be associated with the feminine." But, succinct divisions of the polity as public and the domestic sphere as private are as realistic and possible as putting Humpty Dumpty together again. All BMMs need to do is use the "brain of law" and the view from nowhere, to hide the inconvenient parts of life and to designate them as private" - or "public" - as it suits them. ${ }^{79}$ If we look in the space behind the "universal citizen" as defined by the "brain

75 As mentioned above, this was the case with Carrie Buck's sister, Doris, who was told she was having an appendectomy and in fact, was sterilized. She later learned this when she and her husband tried to have children.

76 Margaret Thornton, Sexing the Citizen, at http://www.law.unimelb.edu.aw/events/citizen/thorton. pdf, last accessed 17 November 2007. Having encountered a number of female partners in large American law firms, I would add to this definition the phrase, "...or women who subscribe to that normative standard as embodied in these males and cannot be distinguished from males based on her actions.” 77 Ann Rudinow Sætnan, Nelly Oudshoorn and Marta Kirejczyk (eds.) in Bodies of Technology (Columbus: Ohio State University Press, 2000), 6. The reference is to R.W. Connel, Gender and Power: Society, the Person and Sexual Politics (Cambridge: Polity Press, 1987).

78 Ibid., 2.

79 Ibid., 4. 
of law", an abstract citizen devoid of all characteristics, what we find is a transition from "private to public patriarchy." 80

Having said the above, I also realize that there can be a problem with this description of patriarchy. As Vanessa Monroe writes, this type of "overly deterministic understanding of the operation of patriarchy" can rest on a problematic understanding of what the interests of women - and men - actually are. ${ }^{81}$ While a monolithic vision of patriarchy may indeed not be very helpful, it does give a starting point for evaluating the effects of various historic forms of patriarchy. ${ }^{82}$ Because I focus on effects, the "potential paralysis" of women engaged in the "how" of combating a patriarchy need not be analyzed here. ${ }^{83}$

All of the above dovetails nicely with the ideas of sociologist Charles Lemert. The "strong we", and the "weak we", are terms developed by him. ${ }^{84}$ The little word "we", he writes is "very potent" and "its value is necessarily derived from the sociology of any situation in which it is used." 85 His example of the language in the American Declaration of Independence is instructive. When that document says "We hold these truths to be self-evident", the "we" refers to a class of powerful white men who "already had the right to use the words 'self-evident'." 86 The relationship between the "strong we" and the "weak we" is that the "weak we" are in the position to ask "Whose We?" as when Jefferson wrote the Declaration of Independence. ${ }^{87}$ While not always "self-consciously cruel", it is the "strong we" that:

throw up barriers of various kinds - fences around refugee camps, gated walls around clusters of fancy homes, and reinforced perimeters on borders with regions where there is an unusual number of the "Weak We" people. ${ }^{88}$

Case One will set out in detail who the "weak we" were who later become part of the "strong we" in Case Two.

80 Ibid. Thornton cites to Sylvia Walby, “Is Citizenship Gendered?” in Sociology, 28 (1994), 379, 392. 81 Vanessa Munroe, Law and Politics at the Perimeter: Re-Evaluating Key Debates in Feminist Theory (Oxford and Portland, Oregon: Hart Publishing Company, 2007), 32.

82 Ibid.

83 Ibid., 33.

84 Charles Lemert, Dark Thoughts: Race and the Eclipse of Society (New York and London: Routledge, 2002), 54-55, 66.

85 Ibid., 52.

86 Ibid., 54.

87 Ibid., 58.

88 Ibid., 59. 


\subsection{Moral Panic and Large-Scale Structural Change}

The idea of moral panic is visible in 1964, when Britain's Daily Telegraph reported a "Day of Terror by Scooter Groups" in Clacton, Britain. ${ }^{89}$ The Daily Mirror went on to report "Wild Ones Invade Seaside" which sociologist Stanley Cohen, who then coined the phrase "moral panic" in his seminal work, Folk Devils and Moral Panic. ${ }^{90}$

The idea of a "moral panic" was also used by Mary Douglas, for one, who observed that during "times of social crisis, when natural borders and identities are threatened, there is likely to be a concern with the maintenance of existing bodily boundaries and the purity of bodies." ${ }^{91}$ I argue that the framing of some discourses related to race/ethnicity, gender, class, ability and citizenship status occur during socially stressful and times of change and that this matters a great deal in terms of the end legal product of the times, i.e. legislated law. ${ }^{92}$

We know, for example, that individual or communal "distress" is sometimes converted into a medicalized illness that is, at that particular moment, considered "deviance" ${ }^{93}$; in a similar manner a form of societal "moral panic" may accompany

89 Please see, http://bbc.co.uk/onthisday/hi/dates/stories/may/18/newsid_2511000/2511245.stm, last accessed 20 June 2009.

90 Stanley Cohen, Folk Devils and Moral Panics: The Creation of the Mods and the Rockers (London: MacGibbon \& Kee, 1972).

91 Chris Shilling, The Body and Social Theory (London, Thousand Oaks, New Dehli: Sage Publications, 2005), p. 64. Please also see Mary Douglas, Natural Symbols: Explorations in Cosmology (London: The Cresset Press, 1970).

92 The concept of "framing" originated with Erving Goffman (1922-1982). (Erving Goffman, Frame Analysis: An Essay on the Organization of Experience (New York: Harper \& Row, 1974). But over the ensuing thirty or more years, the concept can be only "loosely connected" to Goffman's original ideas. (Please see, http://www.lboro.ac.uk/research/mmethods/resources/links/frames_primmer.html, last accessed 3 May 2007.) It even "spans a number of disparate approaches" which are "incompatible with one another." (Ibid.) In fact, Robert Benford tells us it has become a bit of a "cliché." (Robert Benford, "An Insider's Critique of the Social Movement Framing Perspective" in Sociological Inquiry, 67 (1997), 409-430) But one path away from "cliché”, I believe, is to clearly distinguish frames from ideology and ideology from the "master-frame." In addition, in 2000, Benford and Snow asked if the framing literature at that point in time could be said to "congeal or hang together in a fashion suggestive of a coherent perspective" or if "such a perspective [can] be stitched together from various strands of the literature...." (Robert D. Benford and David A. Snow "Framing Processes and Social Movements: An Overview and Asssessment" in Annual Review of Sociology, 26 (2000), 611- 639. Their goal was to refine and integrate the relationship between framing and social movements and, through a substantive review of the literature, they found in the affirmative to both questions.

93 Please see the discussion of "Draptomania" above. The idea of social crisis as part and parcel of causation has also impacted the environs of medical anthropology so that, in 1999, Susan M. DiGiacomo could entitle an article "Can There be a 'Cultural Epidemiology'?" In this work, she cites to the realization by Roberto Franzosi, a quantatively trained sociologist, that history was often treated as a “"warehouse of data' to be plundered...” Realizing that his statistical work reflected correlations and 
the changing of cultural meanings, values and norms. ${ }^{94}$ I do not intend to prove this as a type of rule pertaining to all social and/or cultural upheavals, but only to suggest that it can be a sociological model that can occur, at least in the two cases I present, in the United States and northern Europe..$^{95}$

Furthermore, when societal panic/stress or structural shifts do occur, and when the law becomes involved through either legislative activity or through the appellate interpretation of a set of facts or legal rules applied to those facts, especially in tandem with then "sound" scientific evidence, the panic can flow from this law to bodies that are (often) not male and are (often) not white, with more power and consequence than to the bodies that the law may have originally intended as its subjects and objects (index).

For social constructivists Erich Goode and Nachman Ben-Yehuda, the reality of social problems can be measured or manifested in some of the following ways:

(i) organized, collective action or campaigns on the part of some of the members of society to do something about, call attention to, protest, or change (or prevent change in) a given condition in short, "social problems as social movements"...(ii) the introduction of bills in legislatures to criminalize or otherwise deal with the behavior and the individuals supposedly causing the condition...(iii) the ranking of a condition or an issue in the public's hierarchy of the most serious problems facing the country,...and (iv) public discussion of an issue in the media in the form of magazine and newspaper articles..., commentaries,...and dramas... ${ }^{96}$

This grass-roots social model posits that the panic is spontaneous across the society and is propelled by social stresses. The anxiety is displaced onto deviants of one sort or another "who are perceived through cultural symbols, which reflect the real, underlying social stresses." 97 The elite-engineered model uses major institutions -

not causal relationships, Franzosi cited to Braudel, bemoaning the fact that "there is hardly ever any real dialogue between sociologist and historian....and no marriage between two disciplines that would seem to be ideally suited mates." Please see, Susan M. DiGiacomo, "Can there be a 'Cultural Epidemiology'?” in Medical Anthropology Quarterly, New Series, 13 (1999), pp. 436-457.

94 Margaret Lock, "Cultivating the Body: Anthropology and Epistemologies of Bodily Practice and Knowledge" in the Annual Review of Anthropology, 22 (1993), 145.

95 Catastrophic changes can also be a factor in social/moral panics, e.g. changes in weather. A good overview of various types of crises can be found in American Historical Review Forum, "The General Crisis of the Seventeenth Century Revisited" in The American Historical Review, 113, No. 4 (2008), 1029-1090. J.B. Shank finds that when used as a "rhetorical term of art rather than as a literal term of scientific and deterministic objectivity, the concept of crisis becomes a powerful tool in Negri's historical analysis of Descartes" and that Rabb's use of the "crisis idea works to open interpretive perspectives, not to shut them down in the name of causal determinism.” (p. 1098.)

96 Erich Goode and Nachman Ben-Yehuda, "Culture, Politics, and Social Construction”, in Annual Review of Sociology, 20 (1994), 152.

97 Jeffrey S. Victor, "Moral Panics and the Social Construction of Deviant Behavior: A Theory and Application to the Case of Ritual Child Abuses" in Sociological Perspectives, 41 (1998), 546. 
law, medicine, religion - to "generate and sustain moral outrage" against the deviant group." 98 The intention of the elite group, however, is not to solve the "problem." The intention is to "divert attention away from real problems in a society, the solution of which would threaten the economic and political interests of the elite." ${ }^{\text {"99 }}$ The interest group model "suggest that moral panics are unintended consequences of moral crusades launched by specific interest groups and their activists..."100 While the interest groups may be true believers in their cause they are not averse to having the panic function as a boost to their own goals and prestige.

In some form or another, the concept of "moral panic" cannot be denied; it lives on in the literature. ${ }^{101}$ R.J. Holton uses the term "sociology of crisis" in his analysis of crises, which has its roots in both Talcott Parsons and Jurgen Habermas. ${ }^{102}$ More recently, Ronald N. Jacobs writes about civil society and crisis as reflected in the Rodney King beating. ${ }^{103}$ The term also has a function. Thomas Olesen has written about transnational social movements and one of the nine features he identifies with a successful framing of issues is that these frames, such as a moral panic about race suicide, will have a "well-developed elements of diagnosis, prognosis and motivation and establish a coherent internal relation between them." As well, these frames of moral panic will attempt "to provide order and guidance in a complex reality."104 Moral panic may not be as specific as we would like but it does function in the way that Olesen describes, i.e. it provides a theoretical basis for how to reestablish order again.

Case One and Two take place within the span of nearly 100 years. Can we ignore this as a factor and focus strictly on the Jasanoff fields? We probably could as these fields give evidence of large scale structural change in both the USA and Norway. However, there is a rather succinct model that does the same theoretical work. The Pescosolido model envisions the "modern" or "contemporary" social structure as a circle of intersecting circles all tied by spokes to the individual in the middle of the circle. This emphasis on a new type of network that the individual is engaged in is,

98 Ibid., 547.

99 Ibid. One of the best descriptions of this from medieval times is found in R.I. Moore, The Formation of a Persecuting Society: Power and Deviance in Western Europe, 950-1250 A.D. (Malden and Oxford: Blackwell Publishers, 1987).

100 Ibid., 548.

101 Please see, Erich Goode and Ben-Yehuda Nachman, "No Need to Panic: A Bumper Crop of Books on Moral Panic" in Sociological Forum, 15 (2000), 543-52.

102 R.J. Holton, “The Idea of Crises in Modern Society” in The British Journal of Sociology, 38 (1987), 502-520.

103 Ronald N. Jacobs, "Civil Society and Crises: Culture, Discourse, and the Rodney King Beating” in The American Journal of Sociology, 101 (1996), 1238-1272.

104 Thomas Olesen, "World Politics and Social Movements: "The Janus Face of the Global Democratic Structure” in Global Society, 19 (2005), 125. 
for these authors, a "bridge" between "postmodernism's concern with the individuals' unique experiences and sociology's focus on social structure." ${ }^{105}$ In this new diagram, individuals are not in any of the surrounding interconnected circles but are outside of all of them. The diagram underscores the idea that social life today is "based on serial, ephemeral, short-term, contingent relationships with comparably limited contracts."106 This contingency is only exacerbated by the fact that the groups themselves can also be temporary. The "family", for example, can be represented by many social circles where the only secure ties between these different social circles are the children. ${ }^{107}$

Along with the advantage of more freedom and flexibility comes the disadvantage of "alienation, isolation and fragmentation." 108 If one focuses on the disadvantages, one could see a

return to primordial social ties, reflected in hyper-nationalism, ethnic identity, and religious fundamentalism....[where t] hose who profit from the new social forms are likely to be those in power (as in all social forms), those who are resource rich, and those on the cutting edge of societal developments, i.e. technology. ${ }^{109}$

With the individual at the center of the spoke, there is a capacity for "enormous" egoism along with an "underlying numbness"; unique problems are presented for the creation of responsive social policy formation. ${ }^{110}$

\subsection{Methodologies for Rhetorical Analyses}

Having presented the theories that guide what data I select, I finish this chapter with a discussion of the theories that help those decisions. The first theory is that of critical discourse analysis (CDA) which is a supplement to Jasanoff's "making discourses" field. It is a very common tool with its roots in the "hermeneutical" and "linguistics" turns of the 1980s. Among its chief theoreticians and practitio-

105 Ibid., 62.

106 Ibid., 63.

107 Ibid., 64. Pescosolido-Rubin and Rubin refer to this phenomenon as "stability within change."

108 Ibid.

109 Ibid., 65.

110 Ibid. Originally, this manuscript was to have a Case Three on ultrasound laws that represented the current period. 
ners are Bernstein ${ }^{111}$, Norman Fairclough ${ }^{112}$, Theo A. von Dijk ${ }^{113}$ and Theo von Leeuwen. ${ }^{114}$

There are a number of rhetorical techniques associated with CDA. One is the identification of ideology in a text. Ideology includes ideographs, narratives, myths, characterizations and other discursive units. ${ }^{115}$ Ideology works within a society to condition it to accept one or another "warrant or excuse" for action or a set of beliefs. ${ }^{116}$ It is also an "essential ingredient in the value structure of a particular community."117 Ideographs, which are ultimately abstract value terms such as the term "family", serve as "powerful warrants for when members of a collective are willing to take some social action because of their beliefs." ${ }^{118}$ People who, as agents, affect social action use ideographs; they are thus intimately connected with social constructions. The practical effect of ideographs is that their use may not need the use of coercion. ${ }^{119}$ They are different from "narratives" in that narratives are "stories that are used in the formation of ideologies." ${ }^{120}$ While ideographs are more likely single words or phrase, the narrative has a plot and is longer and meant to be retold. Individuals can then choose between competing narratives. Characterizations are "subcomponent elements of narratives" that are made of "agents, acts, scenes and purposes" and taken to fairly accurately represent a class. Myths are larger and are usually stories about "origins and destinies, explanations or pedagogic images of nature and humanity." 121

111 Please see, Basil Bernstein, The structure of pedagogic discourse: Vol. IV Class, Codes and Control: (New York and London: Routledge, 1990).

112 Please see, Norman Fairclough, Analysing Discourse: Textual analysis for social research (London and New York: Routledge, 2003). This is a fine book with numerous examples ranging from analysis of conversations to cigar wrappers.

113 Please see, T.A. von Dijk (ed.), Discourse, Structure and Process (London and Thousand Oaks: SAGE Publications, Ltd., 1997) and Teun A.Van Dijk, "Chapter 18 Critical Discourse Analysis" in Deborah Schiffrin, Deborah Tannen and Heidi E. Hamilton (eds.) The Handbook of Discourse Analysis, (Malden, Oxford and Victoria: Blackwell Publishing Ltd., 2003), 352-72.

114 Theo van Leeuwen, "The representation of social actors", in Carmen Rosa Caldas-Coulthard and Malcolm Coulthard (eds.), Texts and Practices: Readings in Critical Discourse Analysis. Also, Theo van Leeuwen and Ruth Wodak, "Legitimizing immigration control: A discourse - historical analysis" in Discourse Studies, Vol. 1. No. 1 (1999), 83-118.

115 Marouf Arif Hasian, Jr., The Rhetoric of Eugenics in Anglo-American Thought (Athens and London: The University of Georgia Press: 1996), 159.

116 Ibid., 160.

117 Ibid.

118 Ibid., 171. Citing to Celeste M. Condit, "Democracy and Civil Rights: The Universalizing Influence of Public Argumentation" in Communication Monographs, 54 (1987), 1-18.

119 This idea subverts the ideology of law that it is needed because it is the only thing that prevents anarchy. Law as the basis of social control is highly overrated but, control aside it is probably needed for decisions in tough cases.

120 Ibid., 160.

121 Ibid., 161. Citing to Lewis, William “Telling America’s Story: Narrative Form and the Reagan Pre- 
These theories are useful in analyzing the ideological rhetoric in both the Indiana legislature and the Norwegian Parliament. For example, a participant of the Parliamentary committee that debated the Norwegian sterilization law of 1934 analogized the mentally ill and developmental delayed to parasites on the body politic of the nation; they were just like weeds to a farmer and, as such, they cost the nation of Norway millions of kroner very year. The ideological rhetoric in the state of Indiana 1907 was essentially no different.

In this case, the word "parasite" is an example of a rhetorical ideograph. ${ }^{122}$ In 1930, well before Hasian's use of the ideograph, Michael McGee proposed the idea of an ideograph as a method of understanding the link between rhetoric and ideology. ${ }^{123}$ An ideograph can be defined, as follows:

An ideograph is an ordinary language term found in political discourse. It is a high-order abstraction representing cohesive commitment to a particular but equivocal and ill-defined normative goal. It warrants the use of power, excuses behavior and belief which might otherwise be perceived as eccentric or antisocial, and guides behavior and belief into channels easily recognized by a community as acceptable and laudable. ${ }^{124}$

McGee's definition of an ideograph and Hasian's enhancement of it help us to analyze newspaper and legislative rhetoric. Other examples of ideographs, especially those associated with intersubjective categories are "family", "healthy people", and "motherhood."

Yet another question presents itself with respect to ideographic narratives or discourses that then intertwine with representations and identities. If societal norms and social action are so intertwined and if they exist on several different layers at the same time, how can these processes possibly be studied? It seems impossible and that one is left with either unmanageable qualitative description or the other extreme of only statistical significant variables.

Various researchers have tried different approaches to this problem. Sociologist Georges Gurvitch (1894-1965) has divided the world along a horizontal, "micromacro" axis, in much the same way as I do in my discussion of the microtome, below. Gurvitch's horizontal axis, from the micro- to macro-level, includes forms of sociality, groups, social class, social structure and global structures. To this he added, on a vertical level, the most objective social phenomena such as ecological factors and organizations and ending at the "deepest" level subjective social phenomena such

sident” in The Quarterly Journal of Speech, 73 (1987), 280 -302.

122 Use of the word "parasite" has lately been recycled in Norwegian politics to refer to those absent from work due to sickness. Please see http://www.db.no/forsiden/politikkSamfunn/article 1816139. ece, last accessed 1 April 2010.

123 Michael Calvin McGee, “The 'Ideograph': A Link Between Rhetoric and Ideology” in The Quarterly Journal of Speech, 66 (1930), 1-16.

124 Ibid., 15. 
as collective ideas/values and, even, the "collective mind." 125 Gurvitch's vertical level includes, from the objective to the subjective extremes, along a vertical continuum, 1. actors, actions, interactions, bureaucratic structures, law and so forth, 2. mixed types, combining in varying degrees objective and subjective elements, examples include the state, family work world, religion, and 3. social construction of reality, norms values and so forth.

Sociologists George Ritzer and Jeffrey Alexander have since revised the Gurvitch model. The Ritzer model eliminates the multiple levels of Gurvitch. George Ritzer "crosscuts" the two continua (macro-micro and subjective-objective), ending up with only four levels of social research. ${ }^{126}$ Ritzer locates "law" in the upper left hand quadrant, i.e. objective and macro-leveled and describes this model as symbolizing a "snapshot' in time" and yet "embedded in an ongoing historical process." 127 While this is an attractive model, I believe that Ritzer makes the same mistake about the law as most non-sociologists of law generally make, namely as "objective."

Gurvitch, Ritzer and Alexander aside, what I have done here is to use the newspapers from each country as indicative of what existed at all three levels, making sure to examine both what were described at the time as "conservative" newspapers and "liberal" newspapers. I believe this time-honored way of trying to capture the micro-, meso- and macro- levels was a manageable way of proceeding since stories about individuals at the micro-level are often alongside macro-level institutional stories, etc.

125 George Ritzer, Sociological Theory, 7th Ed, (Boston, etc.: McGraw-Hill, 2008), 502.

126 Ibid.

127 I should note, at this point, that when I conceptualized my own research, I also constructed a diagram that I considered would give me a "snapshot" of a historical process at any given point in time. It was based on my use of the microtome, a device that biologists (used to) use to slice an organ, tissue or group of cells embedded in paraffin. I reasoned that if I could make a very, very thin slice of an organ, then surely I could do the same with an historical phenomenon. I have since been convinced that this is not entirely possible which leads me to my reservations of this model. 